\title{
The Role of Public Relations in Implementing City Branding in "Pasar Raya" in the Covid-19 Pandemic
}

\author{
Fitri Adona*, Yusnani, Sri Nita \\ Politeknik Negeri Padang \\ Padang, Indonesia \\ *fitriadona@pnp.ac.id, yusnani57@gmail.com, srinita0610@gmail.com
}

\begin{abstract}
Public relations of city government have important roles in creating city branding. City branding is used to establish a strong positioning in the mind of the target market like the positioning of a product or service, so Padang c can be recognized regionally and globally. The research on the role of public relations of Padang City Government in implementing city branding in Padang's main market, Pasar Raya, which became a city branding icon of West Sumatra in Covid-19 pandemic was conducted using descriptive qualitative method based on the results of interview, documentation, and observation. The results showed that information and publication on the handling of Covid-19 in West Sumatra were carried out in one door through spokesperson from Regional Information and Documentation Management Officer (PPID) or certain officer that was appointed by the head of the local government, in this case Humas Relations of West Sumatra Province. Public Relations of Padang City Government, in its practice, are assigned to serve the head concerning with protocol affairs, documentations, and the publications of the activities of the government head that are not related with the handling of city branding and Covid-19.
\end{abstract}

Keywords - the role of public relations, city branding, halal tourism, trade center of Padang, Covid-19, kampuang jao

\section{INTRODUCTION}

The fact that Padang's main market, Pasar Raya Padang, was the biggest cluster of Covid-19 spread in West Sumatra adds to problems faced by Padang in developing city branding "Padang Halal Tourism". Pasar Raya Padang is regarded as a storefront reflecting Minangkabau tribe in West Sumatra and the branding of Padang city. Since Minangkabau tribe is identically Moslem, all products and services in Pasar Raya Padang are regarded halal.

Actually Padang's winning achievement in the competition of "World's Best Halal Culinary Destination" 2016 and "World's Best Halal Destination" 2016 makes city branding "Padang Halal Tourism" immediately attached to this city. Previously, the branding of Padang is not specific and it is similar to that of other cities and regencies in West Sumatra since this province also uses the same branding. Besides that, the pattern and concept of "halal tourism" haven't been created well yet even though its citizens are moslem in majority.
The measurement of a place brand performance is often being ignored by public authority and brand consultant. On the other hand, several indicators should be developed in determining the impact of the brand onto the place itself. The current analysis concerning districts in Poland, Hereźniak et al. [1] stated that the measurement of imaging effectiveness of a city brand is not sufficient in evaluating its outcomes, results, and the impacts of city branding strategy. They propose their own-made approachment on how the indicator must be arranged in carrying out well performed verification function towards the practice of territorial entity branding.

The same case also happen in some regions in Indonesia. Local governments take initiative to create branding although it does not show the uniqueness of the regions. Surabaya, for example, introduces "Sparkling Surabaya" which, in fact, has been used by Korea with its "Korea Sparkling". Bandwagon character or "me too brand" also can be seen from "JogjaNever Ending Asia" and "Semarang-The Beauty of Asia" that use the words "Asia". The action without deep analysis is considered as a dangerous blunder [2]. Concerning with it, cooperation with the central government and between regions needs to be improved, so place branding that will be sold are more numerous, extensive, and various [3].

Taken for example big cities in Iran where all of them put so much effort in designing profile on what they are thinking and needing. However, several of adopted city branding strategies are not sophisticated. In general, comparing to other cities in other countries, cities in Iran put special attention onto the aspects of history, nature, culture, and religion [4]. This finding shows that city branding is an integral part of multilevel city governance, highlighting how can a city branding related to national, regional, and local level. It also illustrates on how the strategy and practice of city branding is taken in deciding and implementing city policy supported by the city' growth [5].

Theoretically, halal tourism is a study that has been flourishing in recent years. The use of this term is also various and still being debated, and its principles or the main requirement have not been agreed upon. However, the availability of halal food, pork-free products, and non-alcoholic beverages, and prayer room facilities including wudhu place, 
Al-Qur'an, and prayer equipment (shalat) in the room, qiblat directon, and staff's polite clothes are the requirements that can create moslem-friendly atmosphere [3].

The result of Hankinson branding model acknowledges that out of five dimensions, branding reality is the branding orientation which is considered more significant in influencing the community branding commitment, followed by partnership, culture, and department coordination branding. Besides that, the result of this current research points out the behaviour of branding citizenship determined by the branding commitment resulting branding pride. The use of branding orientation can influence the behaviour of branding citizenship through branding commitment, and definitely this branding citizenship can increase the branding pride [6].

West Sumatera needs to re-design and implement its city branding. The strongest brand is the one that can make and keep its promises to its consumers; representing institution characteristics and aspiration; establishing different institution compares to its opponents; creating emotional relationship with its customers; becoming the lead for the institutions and its members [7].

West Sumatera's bureaucrats have not yet capable in elaborating the consequences of the understanding on regional branding. Most of the products offered are still in the form of promises which is not in accordance with the occurrence in the field. Even though local government has succeeded in establishing a brand, it fails in socializing it. Each slogan made has not yet able to uncover the potential of each region [8].

One of the obstacles in the development of halal tourism in City of Padang is the human resource factor which should be improved. It should be performed in all related parties so that the tourism developer can be more hospitable in serving their guests. Even though the majority of Padang' people are muslin, the tourism facility still in need of halal label, starting from the hotel, restaurant, hair salon, boutiques, tourism site, and others [9].

This current research was conducted in order to evaluate the work performance of public relations in the city of Padang which is highlighted in the establishment of institution/ agency taking a role as coordinator. As a coordinator, these institutions must be responsible in implementing the concept of city branding, dividing the job desk of each stakeholder, and conducting a public discussion on vision, mission, and strategy that will be and has been carried out. It is expected that through this research the efforts put by the local government, particularly public relations and the community in implementing their city branding: "Padang Halal Tourism" can be enhanced.

On the other hand, public relations, especially government public relations, have important roles in creating city branding because of their functions in securing government policies; servicing, and spreading messages and information concerning with policies and working programs nationally to the society; being a communicator as well as a proactive mediator in bridging the interests of government agencies and accommodating public aspirations; and creating a conducive and dynamic climate in order to ensure stability and security [10]. In several private agencies, public relations is a strategic management function. In order that the strategic function works well, its position should be under the top leadership, so it has authority that enables this function to be carried out effectively, given negative effects, major drawbacks, and even the company's image that will be disturbed in the crisis time [11].

\section{METHODS}

This research used descriptive method, which is meant to investigate the status of a human group, an object, a system of thought, or a class of event in the present. A descriptive research only describes a situation or an event. This research does not search for a relationship, test a hypothesis, or make a prediction.

In this context, the researchers try to describe the roles of Padang government in implementing Act No. 23 of 2014 on Local Government as it was changed several times, and the last one is the Act No. 9 of 2015 on the Second Change over Act No.23 of 2014 on Local Government. This act gives local autonomy and places the cities as the center of economic growth, including in developing city branding. Since the main engine of local economic growth is investment, local government is able to make various offers to investor candidates to invest in their region. The researchers also try to analyze obstacles faced by Padang government in implementing the Act, including in implementing and maintaining city branding of "Padang Halal Tourism".

A descriptive research studies problems in the society and customs in a society and certain situations including activities, attitudes, views, and ongoing processes. Sometimes the researchers conduct a classification and research on phenomena by exploring and providing a complete picture related with the investigated problem and phenomenon. Descriptive research is conducted to systematically describe the researched subject and object.

This research also used purposive sampling with certain consideration to select participants since this research did not use generalization. Key informants were chosen based on their activities and willingness to explore their knowledge and experience consciously. They were selected by the researchers and sometimes recommended by the previously selected informants.

\section{RESULTS AND DISCUSSION}

City branding, in this case, is assumed to be able to increase the city's attractiveness in attracting potential human resources that can drive the city development. According to Voogd in Kavaratzis [12], perceptions of a city or the image of a place can be a component of economic success or failure. One of the concept popularly used in city planning with emphasis on the image is the concept of city marketing through brand creation 
which is known as city branding. This study is expected to get an evaluation of the establishment of an institution that is responsible as a coordinator in the implementation of the regional branding concept, the division of roles in the application of the concept, and public discussion regarding the vision, mission and strategy that will be and have been implemeted. In this case, public relations are considered as the spearhead in accelerating the implementation of the city branding.

The key to success in implementing destination branding is how to build brand positioning and brand identity that are unique and different externally and internally. This differentiates it from product branding which is more concerned on how it looks and is perceived differently externally. Not only does a unique branding consider the condition and competition externally, but also it finds an internal uniqueness that is deeply rooted and becomes the soul of the local community.

The government of West Sumatra, either the province, regencies, and cities have agreed to jointly develop West Sumatra tourism as a halal tourism destination (Coordination Meeting of West Sumatra Provincial Government in 2016). However, the rituality, history, and behavior of the society that refer to halal tourism or what is legalized by Islam - which should be highlighted in branding - are not really found. The uniqueness of the culture, rituals, and community behavior is one of the added values that must be highlighted in branding. In addition, the controversial regional branding of the province, "Taste of Padang", needs to be reexamined because the branding of the province seems to be intended for Padang.

It can be observed from the expression of Kampuang Jao, the trade center of Padang, Indonesia. This area is the main trade center in Padang with the establishment of Pasar Raya Padang, the largest traditional market since the Dutch colonial era. In addition to Pasar Raya, three other modern shopping centers in Padang are Plaza Andalas, SPR Plaza, and Rocky Plaza. Besides that, Kampuang Jao also has health facility, that is an auxiliary health center; educational facilities consisting of 3 units of kindergarten, 1 unit of junior high school, and 3 units of senior high school; and 10 units of religious facilities consisting of 5 units of mosque, 4 units of mushalla (prayer room); and 1 unit of church.

In BPS data (West Padang Subdistrict in Figures of 2017), the area of Kampuang Jao is about $1.63 \mathrm{~km} 2$, with a population of 3,849 people and a density of 2,361 people per $\mathrm{km} 2$. Kampung Jao Village consists of $8 \mathrm{RW}$ and 21 RT. Based on the data from BPS of Padang, the number of small traders in West Padang subdistrict in 2016 was 671 businesses, middleclass traders were 3,749 business, and 7,346 large traders were 7,346 businesses. The distance from the village office to the subdisctrict capital is $3 \mathrm{~km}$, to the capital of the city is 14.20 $\mathrm{km}$, and to the capital of the province is $1 \mathrm{~km}$.

The government of Padang city plans to make Pasar Raya a complete trading and tourism location in the near future. After fixing and structuring the market, the government of Padang city will establish a four-star hotel in Pasar Raya by partnering with investors from Sahid Group. "In Pasar Raya, a four-star hotel will be built. The hotel will be built by the third party, Sahid Group," said the Mayor of Padang, H. Mahyeldi Ansharullah Dt. Marajo, Tuesday (19/2/2019).

The vision of Padang City Government in 2020-2025 is: "Creating a Civilized Padang Community Based on Education, Trade, and Tourism Which are Superior and Competitive". The missions are: improving the quality of education to produce faithful, creative, innovative, and competitive human resources; realizing Padang city which is superior, safe, clean, orderly, friendly, and respects local wisdom; increasing the inclusive economic growth of Padang; realizing Padang as a center of trade and creative economy; improving the quality of tourism management that is comfortable and memorable; creating a disaster-aware, caring, and resilient community, and improving the quality of clean governance and excellent public services [13].

Public relations is defined as all forms of planned communication, both inside and outside, between an organization and its audiences in order to achieve specific goals based on mutual understanding [14]. In this regard, this research seeks to explain and provide input on the role of Public Relations of Padang Government in implementing and maintaining city branding in the trade center of Padang in the Covid-19 pandemic.

Observations show that violations of physical distancing which is the requirement in handling Covid-19 triggered an increase in positive Covid-19 victim in the cluster of Trade Center of Padang and were the reason for the closure of the trade center for a week. It affects the trust in the city branding of Padang. Along with that, the instruction not to use mosques for congregational prayers was released in accordance with the Large-Scale Social Restrictions (PSBB) issued by the Ministry of Health. This further emphasizes that the indiscipline of the citizens has resulted in the important factor promised by the city branding, "Padang Halal Tourism", that has not been accommodated well, especially in halal shopping services and services of worshipping facilities in the middle of trading activities.

Highlighted by Ratnasary et al. [15], public relations is an expert prescriber. As an expert prescriber, public relations, in carrying out its role as an expert determinant, defines problems, makes program planning, takes full responsibility for the implementation of the communication program. As a communication facilitator, public relations acts as a liaison, translator, and mediator between the organization and the public, while as a problem solver facilitator, public relations collaborates with other managers to define and solve problems by implementing management process, starting from analyzing problems, planning, , implementing, and evaluating. In its last role as a communication technician, public relations performs technical operations such as writing and editing magazines, writing press releases, essays, and articles, creating and developing websites, and producing various communication 
messages. Therefore, communication and journalistic skills are needed.

However, the four roles of Public Relations of City Government are not really focused on developing and maintaining city branding in Covid-19 pandemic. Following up on the Regulation of the Ministry of Home Affairs No. 56 of 2019 concerning Guidelines for Nomenclature of Provincial and Regency/City Secretariat Work Units, the Public Relations Section of Padang City Regional Secretariat has changed its name, structure, and function. In the nomenclature, Public Relations Sections changed its name to the Protocol and Leadership Communication Section, consisting of 3 subsections, namely theProtocol Sub-Section, the Leadership Communication Sub-Section, and Leaders' Activities Documentation and Activity Documentation and Publication Sub-Section. With the application of the nomenclature, the task of Public Relations is focused more on serving the leaders related to protocol matters, documentation and publication of leaders' activities which include the activities of the Mayor, the Deputy Mayor, and the Regional Secretary. Public Relations are the eyes and ears of the leaders related to their function as a spokesperson for regional heads (Interview with Amrizal Rengganis, Head of Protocol and Leadership Communication, August 2020).

This is caused by the handling of Covid-19 in West Sumatra that is carried out in one door through a spokesperson from Regional Information and Documentation Management Officer (PPID) or certain officer appointed by the Regional Head, in this case the Public Relations of West Sumatra Province. On the other hand, in the Task Force of the Acceleration of the Handling of Corona Virus Disease 2019, the presence of the Head of Information and Communication Office of Padang City is more prominent. He is the Coordinator of Public Relations and Information whose members are the Head of Protocol and Leadership Communication Sub-Section, Public Relations of BPBD of Padang City, the Head of Program Planning for Padang Health Service. The problem of city branding development is also handled by Tourism Office of Padang City.

However, the Task Force of the Acceleration of Handling of Corona Virus Disease 2019 which was established by the Mayor of Padang tries to guarantee the implementation and maintenance of city branding because its duties are to determine and implement the operational plans, coordinate and control, supervise the implementation; mobilize resources for the implementation of activities; and report the accelerated implementation of the handling of the Corona Viruse Disease 2019. This task is strengthened by the Regulations of the Mayor of Padang No. 49 of 2020 on New Lifestyles during Covid-19 Pandemic that also requires adaptation through changes in lifestyle in Covid-19 pandemic including: schools and educational institutions, workplaces and industries, places of worship, publice places and facilities [including Pasar Raya], social and cultural places, transportation, working/business trips, and home.
Following up on a letter from the World Health Organization (WHO) on a recommendation to Jokowi to announce the national emergency status of the corona virus in Indonesia, the government also created a team to accelerate the handling of the corona virus called the Task Force. The team was formed based on Presidential Decree No. 7 of 2020 on the Task Force for the Acceleration of the Handling of Corona Virus Disease 2019 (Covid-19). In this decree, the President assigned the Head of the National Disaster Management Agency (BNPB) Let.Gen. Doni Monardo as the Chairperson of the Task Force. A rapid reaction team has been formed and commanded by the head of BNPB dan set up in type A hospitals.

The task force aims to increase the anticipation of the escalation of Covid-19 spread and increase the synergy in operational policy making. Furthermore, it aims to increase the readiness and ability to prevent, detect, and respond to Covid19. The Task Force carries out massive handling by involving all national resources through collaboration with local governments, academics, researchers, especially in the field of viruses, the business field, the community including experts and press.

On the other hand, governors, regents, and mayors can form a task force for the acceleration of the handling of covid-19 based on the considerations and recommendations of the Chairperson of Task Force for the Acceleration of the Handling of Covid-19. The Task Force will also involve all corps of the health sector from the government, BUMN, business institutions, non-governmental organizations, universities, and research institutes. All of them will be involved in a planned and integrated way to strengthen the prevention, the acceleration of the detection and response. The real action taken was increasing the number of places for testing for covid19 rapidly, increasing the number of medical personnels by inviting and involving all parties, including final year medical students, doctors from IDI, and other medical volunteers.

In accelerating the handling of the WHO protocol, the Task Force carries out the coordination at national and regional levels, conveys correct and accurate information regarding the risk of transmission and prevention of Covid-19 to the public, carries out surveillance to trace cases, carries out appropriate actions at entrances and exits of Indonesia, forms a rapid reaction team, strengthens the laboratory system, implements prevention and control measures against new infections, implements case management and the continuity of important services to victims/cases, and provides logistic needs, materials, and health facilities.

In connection with the Decree of the President of the Republic of Indonesia No. 7 of 2020 on the Establishment of a Task Force for the Acceleration of the Handling of Corona Virus Disease 2019 (Covid-19) and several circular letters from the related Ministers as well as the Results of the Coordination Meeting of Covid-19 Handling at the level of West Sumatra Province held on Monday, March 16, 2020, the Governor and 
the Regents/Mayors in West Sumatra also made an agreement to be followed up.

In the education sector, in accordance with Act No. 23 of 2014 on Regional Governmet, it is regulated and stipulated that the regulation of the secondary education level (Senior High School/Vocational High School) and SLB (Special Education School) is the authority of the provincial government, whereas the basic education level, starting from Early Childhood Education to Junior High School, is the authority of the city government, so the decision to close the schools was taken by the local government in accordance with their respective authority. To make decisions about the school dismissal at every level of education was based on the Circular Letter of The Minister of Education and Culture No. 3 of 2020 on Prevention of Covid-19 in the Education Unit.

Refering to the Circular Letter, the level of risk of Covid-19 spread in West Sumatra was in the low category at that time, with the criterion: no member of the community was infected by Covid-19, so there was no need to close the schools. At that time, students were or would be in the period of implementing the National Examination, starting from the secondary education level and followed by the basic education level. If it was found that a student was suspected of having Covid-19, the Governor or Regent/Mayor, in accordance with their authority, would close the class or one educational unit for 14 days. In addition, extracurricular activities in or outside the school that had the potential for physical contact with many people were eliminated.

In the tourism sector, tourism players carry out Standard Operating Procedure of Covid-19 handling such as checking body temperature and providing hand sanitizers in all hotels, homestays, tourist buses, and paid tourist attractions that accommodate tourists. If a tourist is found with physical symptoms, he should be reported directly to the local health office or the nearest health facility. Tourism operators are expected to coordinate with the Health Office of Padang Class II Port, Minangkabau International Airport (BIM) Teluk Bayur, Muaro, Bungus, and Sikakap Ports to check the mobility of tourist arrivals and returns at those airports and sea ports.

In the matter of activities, events, or meetings that have been scheduled, their implementation is arranged to be postponed after August 2020. Strategic activities are carried out selectively and attended by a limited number of people. Information and publications regarding the handling of Covid19 in each region are carried out one door through the Spokesperson for the Regional Head, or the Regional Information and Documentation Management Officer (PPID), or certain officers appointed by the Regional Head. The Task Force for the Acceleration of the Handling of Covid-19 based on the consideration and recommendation of the Head of the National Disaster Management Agency (BNPB) as the Chairperson formed the task force for the acceleration of the handling of Covid-19 in each region. However, the task force did not ask opinions from the Public Relations of Padang City Government (For detail see table 1).
TABLE I. COMPARISON OF THE ROLE OF PUBLIC RELATIONS IN IMPLEMENTING CITY BRANDING IN PASAR RAYA

\begin{tabular}{|l|l|c|c|c|}
\hline No & $\begin{array}{c}\text { The role of } \\
\text { Public Relations }\end{array}$ & $\begin{array}{c}\text { Public } \\
\text { Relations } \\
\text { of Padang } \\
\text { City }\end{array}$ & $\begin{array}{c}\text { Public } \\
\text { Relations } \\
\text { of West } \\
\text { Sumatera } \\
\text { Province }\end{array}$ & $\begin{array}{c}\text { Ministry of } \\
\text { Communication, } \\
\text { Information and } \\
\text { Technology of } \\
\text { Padang City }\end{array}$ \\
\hline 1. & Expert Prescriber & 0 & $\checkmark$ & $\checkmark$ \\
\hline 2. & $\begin{array}{l}\text { Communication } \\
\text { Facilitator }\end{array}$ & 0 & $\checkmark$ & $\circ$ \\
\hline $3 . \quad \begin{array}{l}\text { Problem Solver } \\
\text { Facilitator }\end{array}$ & 0 & $\circ$ & $\checkmark$ \\
\hline $4 . \quad \begin{array}{l}\text { Communication } \\
\text { Technician }\end{array}$ & 0 & $\checkmark$ & $\checkmark$ \\
\hline Caption: \\
$\quad=$ have a role \\
$\quad=$ no role
\end{tabular}

\section{CONCLUSION}

The handling of Covid-19 in West Sumatra is carried out by Public Relations of West Sumatra Province. The handling at the City level is carried out by the Task Force for the Acceleration of the Handling of the Corona Virus Disease 2019 formed by the Mayor of Padang. He is the Coordinator of Public Relations and Information whose members are the Head of Protocol and Leadership Communication Sub-Section, Public Relations of BPBD of Padang City, the Head of Program Planning for Padang Health Service. The Task Force or the Acceleration of the Handling of Corona Virus Disease 2019, which was formed by the Mayor of Padang, is trying to ensure the implementation and efforts to maintain city branding. This task is strengthened by the Regulation of the Mayor of Padang No. 49 of 2020 on New Lifestyles during the Corona Virus Disease 2019 (Covid-19) Pandemic. Public relations are a strategic management function. In order that the function runs well, the position of public relations must be under the top leadership so that it has the authority to enable this function to be carried out effectively.

\section{ACKNOWLEDGMENT}

The writers would like to thank Padang State Polytechnic for supporting this research through Excellent Research Grant for Higher Education, with the Research Grant No: .../PL.9.15/PG/2015.

\section{REFERENCES}

[1] M. Hereźniak, M. Florek, and A. Augustyn, "On Measuring Place Brand Effectiveness - between Theoretical Developments and Empirical Findings," Econ. Sociol., vol. 11, no. 2, pp. 36-51, 2018.

[2] G. Eason, B. Noble, and I. Sneddon, "On certain integrals of LipschitzHankel type involving products of Bessel functions," Phil. Trans. Roy. Soc. London, vol. A247, pp. 529-551, 1955

[3] M. Muktiali, "Kaji Banding City Branding Kota Semarang dengan Kota di Indonesia (Solo \& Surabaya) dan Kota Dunia (Kota Amsterdam)," Seminar Nasional City Branding, 2012.

[4] I. De Noni, L. Orsi, and L. Zanderighi, "Stereotypical versus experiential destination branding: the case of Milan city," Cult. Soc., pp. $1-16,2019$ 
[5] L. Ye and E. Björner, "Linking city branding to multi-level urban governance in Chinese mega-cities: A case study of Guangzhou," Cities, vol. 80, pp. 29-37, 2018.

[6] Y. Ahn, S.S. Hyun, and I. Kim, "City Residents' Perception of MICE City Brand Orientation and Their Brand Citizenship Behavior: A Case Study of Busan, South Korea,” Asia Pacific J. Tour. Res., pp. 328-353, 2016.

[7] F. Adona, A. Utaminingsih, and B. Siddik, "Kampanye Komunikasi Pemasaran Sumatera Barat Melalui Branding Communication: Analisis Pekerja Kreatif Industri Pariwisata," Poli Bisnis, vol. 6, no. 1, pp. 89$105,2014$.

[8] F. Adona, "Slogan District and the City: An Analysis of Errors in Writing of English and Language of Indonesia of People of Minangkabau Sumatera Barat,” J. Arbitrer, vol. 2, no. 2, pp. 112-118, 2015.

[9] F. Adona, Y. Yusnani, and S. Sukatik, "Padang Halal Tourism: Studi Kasus terhadap City Branding pada Pusat Perdagangan Kota Padang," J. Ilm. Poli Bisnis, vol. 11, no. 2, pp. 143-153, 2019.
[10] R. Ruslan, Manajemen Public Relations dan Media: Konsepsi dan Aplikasi. Jakarta: Rajagrafindo Persada, 2014.

[11] S. Jessica, "Aktivitas Public Relations Angkasa pura ii dalam menangani pemberitaan negatif terminal 3 bandara soekarno-hattathe activity of public relations of angkasa pura ii in handling negative news terminal 3 soekarno - hatta airport," PRofesi Humas, vol. 2, no. 2, pp. 119-135, 2018.

[12] M. Kavaratzis, "From city marketing to city branding: An interdisciplinary analysis with reference to Amsterdam, Budapest and Athens," Rijksuniversiteit Groningen, 2008.

[13] "Visi dan Misi Walikota Padang dan Wakil Walikota Padang," 2020. [Online]. Retrieved from: https://padang.go.id/visi-misi-walikota-danwakil-walikota-padang

[14] F. Gifari, "Strategi asia pr dalam memperkuat hubungan media dengan forum wartawan otomotif (forwot) asiapr strategy in strengthening media relations with forum," PRofesi Humas, vol. 1, no. 2, 2017.

[15] E. Ratnasary, A. Rahmat, and F.A.A. Prastowo, "Peran Hums Perguruan Tinggi Negeri Badan Hukum dalam Implementasi Kebijakan dan Keterbukaan Informasi,” Profesi Humas, vol. 3, no. 1, pp. 21-38, 2018. 